\title{
The role of palm tree Attalea maripa (Aubl.) Mart. in the fixation of fern communities in edge areas
}

\author{
O papel da palmeira Attalea maripa (Aubl.) Mart. na fixação de comunidades de samambaias \\ em áreas de bordas
}

\author{
J. S. Modesto ${ }^{1}$; P. W. P. Gomes ${ }^{2}$; A. S. Martins Junior ${ }^{1}$; P. S. Medeiros- \\ Sarmento $^{3}$; A. C. C. Tavares-Martins ${ }^{1 *}$ \\ ${ }^{1}$ Universidade do Estado do Pará, 66.050-540, Belém-PA, Brazil \\ ${ }^{2}$ Universidade Estadual de Campinas, 13083-970, Campinas-SP, Brazil \\ ${ }^{3}$ Museu Paraense Emílio Goeldi, 66040-170, Belém-PA, Brazil
}

*tavaresmartins7@gmail.com

(Recebido em 24 de junho de 2020; aceito em 28 de setembro de 2020)

\begin{abstract}
Edge areas of forest fragments are the most exposed to external disturbances. This study aimed to evaluate the palm tree Attalea maripa (Aubl.) Mart. role in conserving the community of ferns from disturbed areas of the Ecological Reserve of the Bacurizal Forest, Salvaterra-PA. A total of 15 excursions were held between July and November 2017 to collect ferns in all living forophytes of A. maripa in disturbed areas. The phorophytes were divided into three ecological zones (base, trunk and sheath) where the ferns were located. The total variables of forophyte height, diameter at breast height; shaft height and sheath insertion height. We found 91 phorophytes of A. maripa with ferns, among which 266 specimens distributed in four species belonging to four families. Phlebodium decumanum (Willd.) J.Sm. (Polypodiaceae) was the most representative fern species with 110 specimens, followed by Nephrolepis biserrata (Sw.) Schott (Lomariopsidaceae) (91), Vittaria lineata (L.) Sm (Pteridaceae) (59), and Lygodium venustum Sw. (Lygodiaceae) (six). The highest representativeness of fern specimens in the ecological zone of the sheath (77\%) it is probably related to the environmental conditions found in this area, which presents low temperatures and higher humidity that favor the establishment and development of ferns. There was no significant correlation between the number of fern specimens with the total height of the phorophyte, diameter at breast height, shaft height and sheath insertion height. A. maripa proved to be an important component for the fern establishment in disturbed environments, especially in the ecological area of the sheath by microclimatic conditions favorable to the colonization of ferns.

Keywords: microhabitat, ecological relations, Salvaterra.
\end{abstract}

As áreas de borda dos fragmentos florestais são porções mais expostas a distúrbios externos. Neste sentido, o estudo avaliou o papel da palmeira Attalea maripa (Aubl.) Mart. em conservar a comunidade de samambaiais em áreas antropizadas da Reserva Ecológica da Mata do Bacurizal, Salvaterra-PA. Foi realizado um total de 15 excursões entre julho a novembro de 2017 para coletar as samambaias em todos os forófitos vivos de A. maripa em áreas antropizadas. Os forófitos foram divididos em três zonas ecológicas (base do tronco, tronco e bainha) onde se encontravam as samambaias. Mediu-se as variáveis de altura total do forófito, diâmetro a altura do peito, altura do fuste e altura da inserção da bainha. Foram encontrados 91 forófitos de A. maripa com samambaias, dentre os quais, registrou-se 266 espécimes de samambaias distribuídas em quatro espécies pertencente a quatro famílias. Phlebodium decumanum (Willd.) J.Sm. (Polypodiaceae) foi a espécie samambaia mais representativa com 110 indivíduos, seguida por Nephrolepis biserrata (Sw.) Schott (Lomariopsidaceae) (91), Vittaria lineata (L.) Sm (Pteridaceae) (59) e Lygodium venustum Sw. (Lygodiaceae) (seis). A maior representatividade dos espécimes de samambaias na zona ecológica da bainha $(77 \%)$ provavelmente está relacionada as condições ambientais encontradas nessa zona, a qual apresenta baixas temperaturas e maior umidade que favorecem o estabelecimento e desenvolvimento das samambaias. Não houve correlação significativa entre o número de espécimes de samambaias com a altura total do forófito, diâmetro a altura do peito, altura do fuste e altura da inserção da bainha. Os indivíduos de A. maripa mostraram-se um componente importante para o estabelecimento das samambaias em ambientes antropizados, principalmente na zona ecológica da bainha pelas condições microclimáticas favoráveis a colonização das samambaias.

Palavras-chave: microhabitat, relações ecológicas, Salvaterra. 


\section{INTRODUCTION}

Habitat loss and changes in the structure of plant communities are growing disturbances in the Amazon and their main causes are associated with deforestation from agriculture [1], livestock [2], road construction [3] and mining [4]. On Marajó Island, although titled as a Conservation Unit and classified as an Environmental Protection Area of Marajó Island for the conservation of biodiversity, has been suffering from constant human pressure to supply the needs of agriculture and timber extraction [5, 6]. Salvaterra, a municipality located in the northeast of Marajó Island, has forest vegetation of dry land, floodplains, mangroves, savannas and restingas. In order to protect some of these areas that have been strongly anthropized by population growth and tourism activities, the Bacurizal Ecological Reserve was created [7], which has been constantly fragmented.

The edge areas of the forest fragments are portions most exposed to external disturbances characterized by the strong influence of the high incidence of light, wind, higher temperature and lower relative humidity of the air [8]. In this sense, the edge of the forest may have a different species composition compared to the interior of the fragment, since only a few species are able to tolerate the environmental conditions of edge [9], such as the palm tree Attalea maripa (Aubl.) Mart. (Arecaceae), which presents great resistance in disturbed environments due to the density of its stem and its apical meristem, positioned below the ground [10]. Attalea maripa (Aubl.) Mart. it is a palm tree with wide occurrence in the Amazon, occurring mainly in secondary forests and silvopastoral systems [11], where they are frequently observed serving as phorophytes for several epiphytes [12]. This characteristic allows greater protection against fires and rapid regeneration and spread of the palm by all types of floristic cover [13], as well as the edge areas of the forest fragments.

The choice of Attalea maripa (Aubl.) Mart. as a habitat sampling unit is mainly justified by the predominance of this species in the Bacurizal Ecological Reserve, according to which it is cited by Lisboa et al. [7] as the most frequent species with 36 specimens, equivalent to $59.01 \%$ of the relative density. The predominance of A. maripa is due, in part, to human intervention through the extraction of trees that resulted in the formation of clearings allowing the intense regeneration of this palm tree [7].

For the establishment of vascular epiphytes in the forophytes, some conditions such as light, humidity, temperature and the morphological characteristics of the phorophytes act as environmental filters that are decisive in the stratification and distribution of abundance of epiphytic species [14]. Among the epiphyte vascular plants, ferns form the second largest group with $29 \%$ richness in the world [15]. Such occurrence of ferns is greater in natural forests in relation to forest fragments that suffer anthropic action [16]. In tropical forests, ferns show significant biomass production, contributing to the stability of microhabitats and maintaining nutrient cycling [17].

The wide biological diversity of seedless vascular plants in the world is closely related to the heterogeneity of habitats that provide distinct environmental conditions, which can induce different processes of plant adaptation [18]. In Brazil, seedless vascular plants form a group that corresponds to 1.253 species (1.111 ferns and 142 lycophytes), with the Atlantic Forest (883 species) being the richest phytogeographic domain continues and also with more endemic and threatened species, followed by the Amazon (503 species), Cerrado (269), Pantanal (30), Caatinga (26) and Pampa (eight) [19]. These data highlight that the occurrence of species is associated with the availability of different habitat heterogeneity conditions in each Brazilian phytogeographic domain.

From the approaches mentioned above, our work was carried out by the following guiding questions: Is the occurrence of the palm tree Attalea maripa (Aubl.) Mart. in edge areas important for maintaining epiphytic fern communities? Have Ferns a distribution pattern on the palm $A$. maripa influenced by ecological zones and phytosiological variables in border areas? We adopted the premise that the highest occurrence of Attalea maripa (Aubl.) Mart. as a habitat unit in the border areas is a factor that plays an important role in the establishment of ferns. To test this, we use indicators such as ecological zones and phytosociological variables. With that, this study 
aimed to evaluate the role of the palm A. maripa in the fixation of fern communities in anthropized areas of the Ecological Reserve of Mata do Bacurizal, Salvaterra, Marajó Island, Pará.

\section{MATERIAL AND METHODS}

\subsection{Area of Study}

The study was carried out at the Ecological Reserve of Mata do Bacurizal $\left(0^{\circ} 466^{\prime 23.6 " S}\right.$; $48^{\circ} 31^{\prime} 08.1^{\prime \prime W}$ ) in the municipality of Salvaterra, Marajó Island, Pará. Despite being an area of environmental preservation, this reserve was marked by strong anthropization associated with deforestation, burning and inadequate tourism. The climate in this study region is humid equatorial with an average temperature of $28^{\circ} \mathrm{C}$ and annual precipitation of $1670 \mathrm{~mm}$ (Instituto Nacional de Meteorologia - http://www.inmet.gov.br/portal/index.php?r=home2/index). According to Lisboa (1993) [7], the studied area consists of firm, open highland vegetation, containing palm trees in sandy and clayey soil.

\subsection{Sampling, collection and taxonomic identification}

There were 15 excursions between July and November 2017 for the collection of botanical material, with the number 51016-1 for approval in the Biodiversity Authorization and Information System (SISBIO). Epiphytic ferns were collected from all live phorophytes from A. maripa in edge areas (Figure 1), where three ecological zones were established base of the trunk, stem and sheath, according to Johansson (1974) [20] with modifications. The adopted phytosociological variables were phorophyte's total height $(\mathrm{TH})$, diameter at breast height $(\mathrm{DBH})$ obtained at 1.30 meters from the soil surface; shaft height $(\mathrm{SH})$ and sheath insertion height $(\mathrm{SIH})$ were measured in meters (Figure 2), according to Kersten and Waechter (2011) [21]. During the collection, information about the location was recorded with descriptions of the collection site and geographic coordinates of latitude and longitude, ecological zone and height from the soil in which the plant was collected.

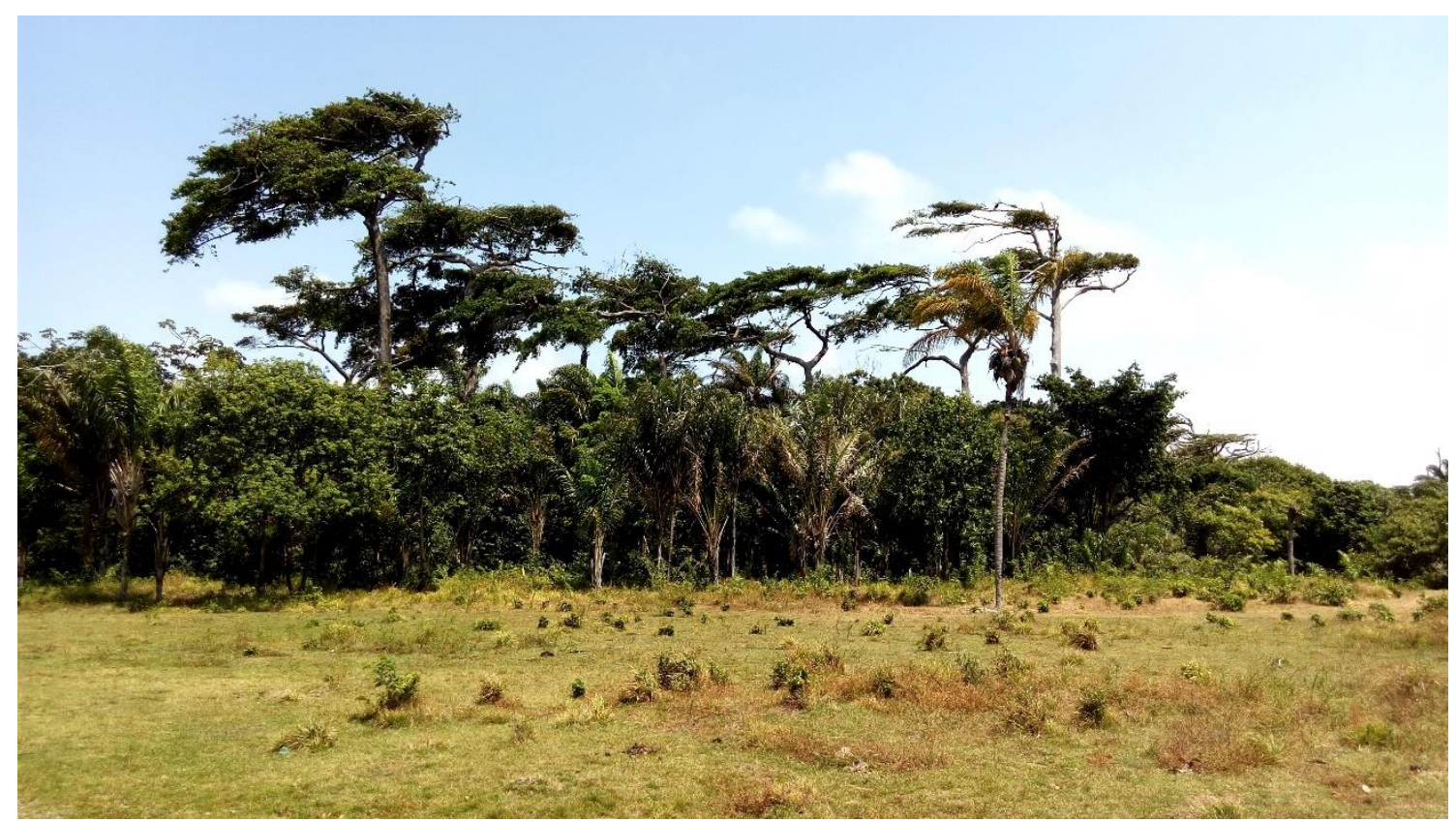

Figure 1: Edge areas in the Ecological Reserve of Mata do Bacurizal, municipality of Salvaterra, Marajó Island, Pará. 


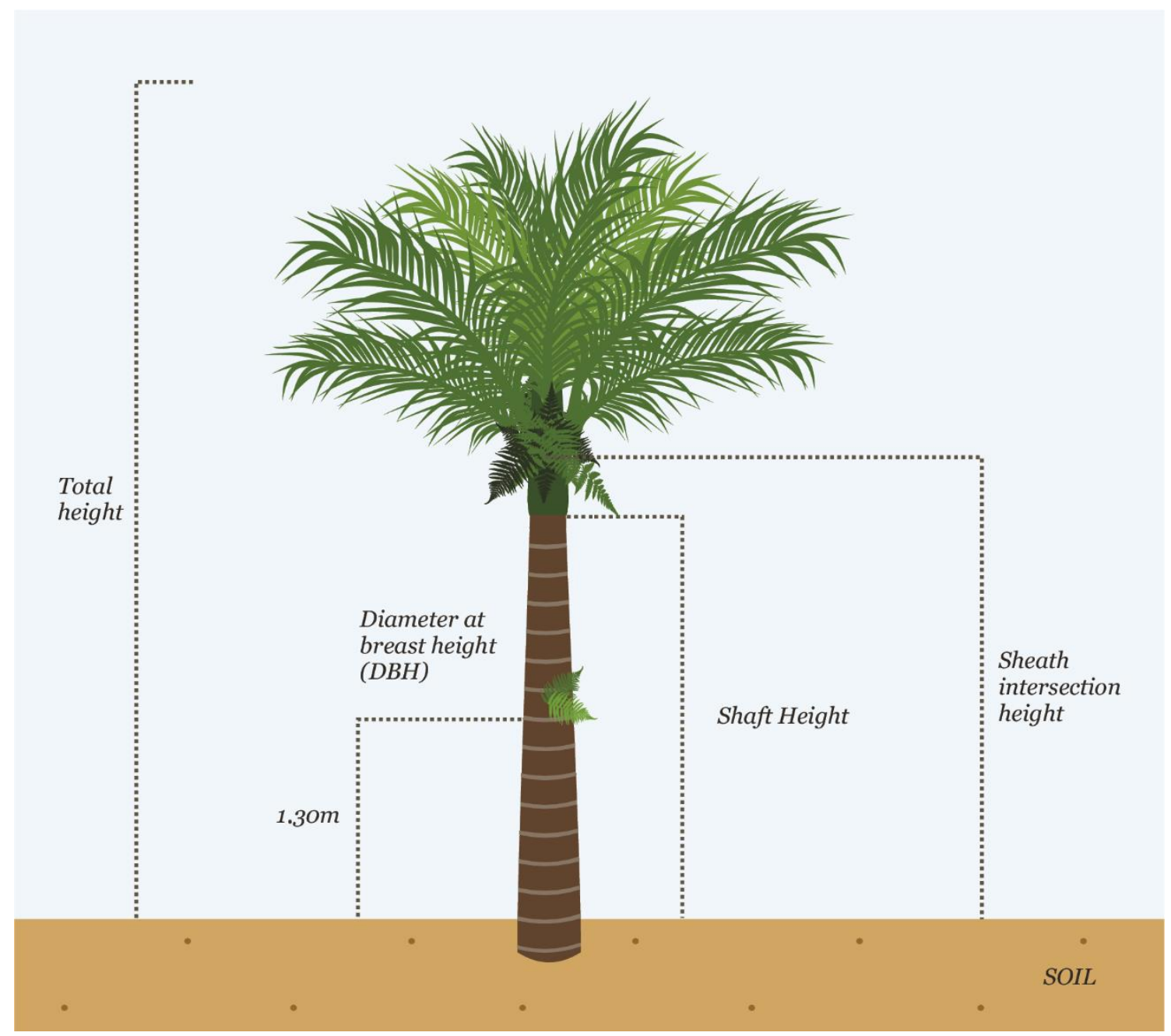

Figure 2: Illustration of the phytosociological variables measured in Attalea maripa (Aubl.) Mart.

The classification of ferns followed the classification system of Smith et al. (2008) [22]. The methods of preserving botanical material followed the methodology of Windisch (1992) [23] and the identification based on specific literature [24]. The database of Flora do Brasil 2020 was used to confirm the scientific names and all the material collected was included in the collection of the Herbário Prof ${ }^{a}$ Dr $^{a}$ Marlene Freitas da Silva (MFS) of the State University of Pará.

\subsection{Data analysis}

The presence and absence of epiphytic ferns and the number of specimens in each phorophyte were analyzed, in the three ecological zones established. To check for differences in the number of specimens along the forophyte, the Mann-Whitney (U) test was used [25]. Spearman's correlation was used to analyze the number of specimens in each phorophyte and their relationship with TH, DBH, SH and SHI. All of these analyzes were performed in the PAST program using a 95\% confidence interval.

\section{RESULTS}

\subsection{Species richness}

We classified and registered 266 specimens of epiphytic ferns of four species belonging to four families (in Table 1 and Figure 3). 
Table 1: List of epiphytic ferns found in Attalea maripa (Aubl.) Mart. of anthropized areas of the Ecological Reserve of Mata do Bacurizal, Salvaterra, Marajó Island, Pará. Ns - number of specimens observed.

\begin{tabular}{lcccccc}
\hline Family/Species & \multicolumn{3}{c}{ Ecological zone } & \multirow{2}{*}{ Ns } & \multirow{2}{*}{ Voucher } \\
\cline { 2 - 4 } & Base & Stem & Sheath & & & \\
\hline $\begin{array}{l}\text { Lomariopsidaceae } \\
\quad \text { Nephrolepis biserrata (Sw.) Schott }\end{array}$ & 0 & 0 & 91 & 91 & MFS008314 \\
$\begin{array}{l}\text { Lygodiaceae } \\
\quad \text { Lygodium venustum Sw. }\end{array}$ & 0 & 0 & 6 & 6 & MFS008331 \\
$\begin{array}{l}\text { Polypodiaceae } \\
\quad \text { Phlebodium decumanum (Willd.) J.Sm. }\end{array}$ & 0 & 11 & 99 & 110 & MFS008313 \\
$\begin{array}{l}\text { Pteridaceae } \\
\quad \text { Vittaria lineata } \text { (L.) Sm. }\end{array}$ & 0 & 49 & 10 & 59 & MFS008323 \\
\hline Total & 0 & 60 & 206 & 266 & \\
\hline
\end{tabular}
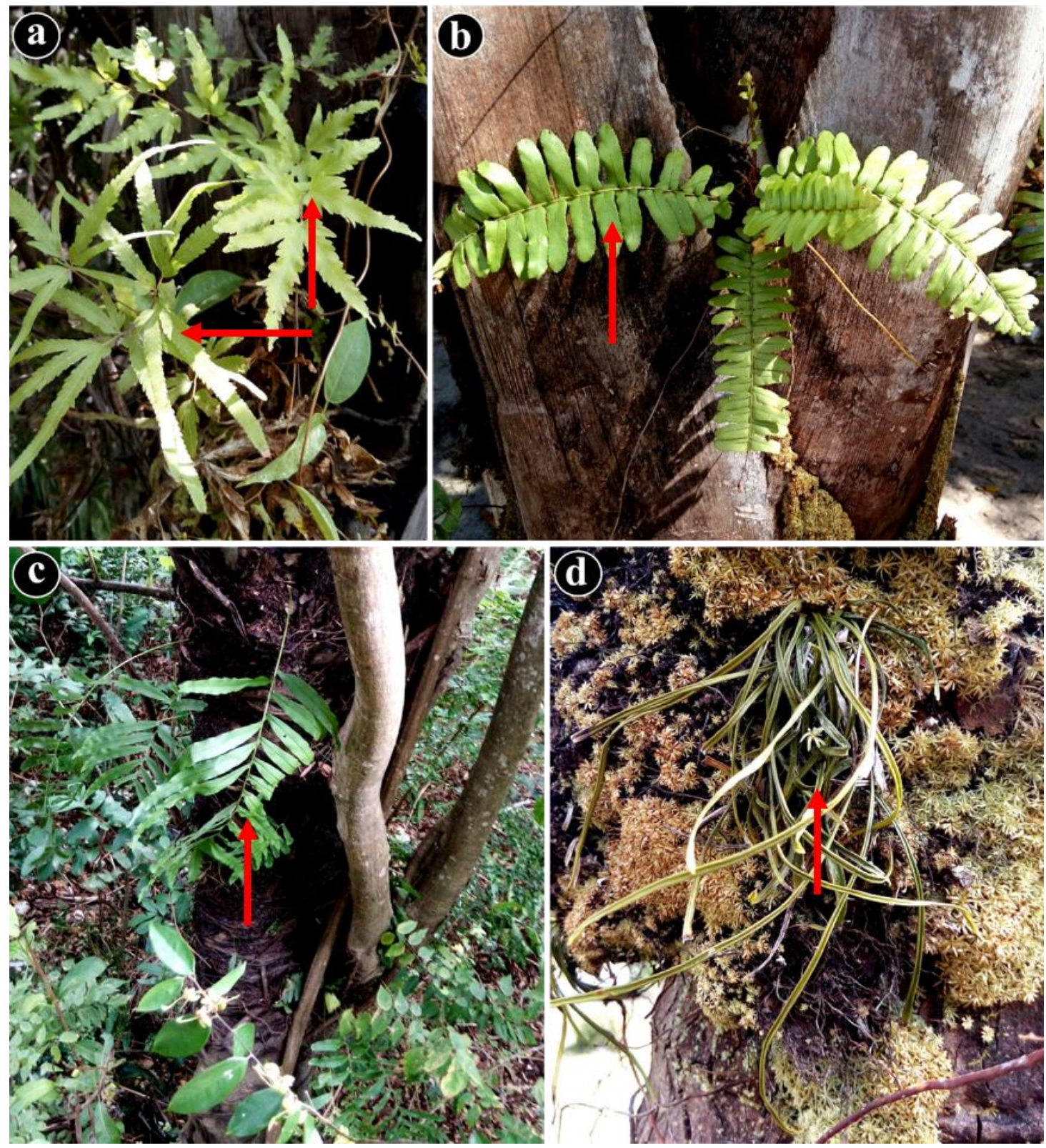

Figure 3: Arrow indicating Fern species in Attalea maripa (Aubl.) Mart. a. Lygodium venustum Sw.; b. Nephrolepis biserrata (Sw.) Schott; c. Phlebodium decumanum (Willd.) J.Sm. and d. Vittaria lineata (L.) Sm. 


\subsection{Ecological zones}

Was observed between the number of specimens that occur in the stem and leaf sheath of Attalea maripa (Aubl.) Mart. ( $\mathrm{U}=26047 \mathrm{p}=0.02$ ) (Figure 4), with a greater representativeness of specimens (77\%) in the ecological zone of the sheath. Among these, the species with the highest abundance were Lygodium venustum Sw. (6 specimens), Nephrolepis biserrata (Sw.) Schott (91) and Phlebodium decumanum (Willd.) J.Sm. (99). Only Vittaria lineata (L.) Sm. (59) presented a higher number of specimens in the ecological zone of the stem.

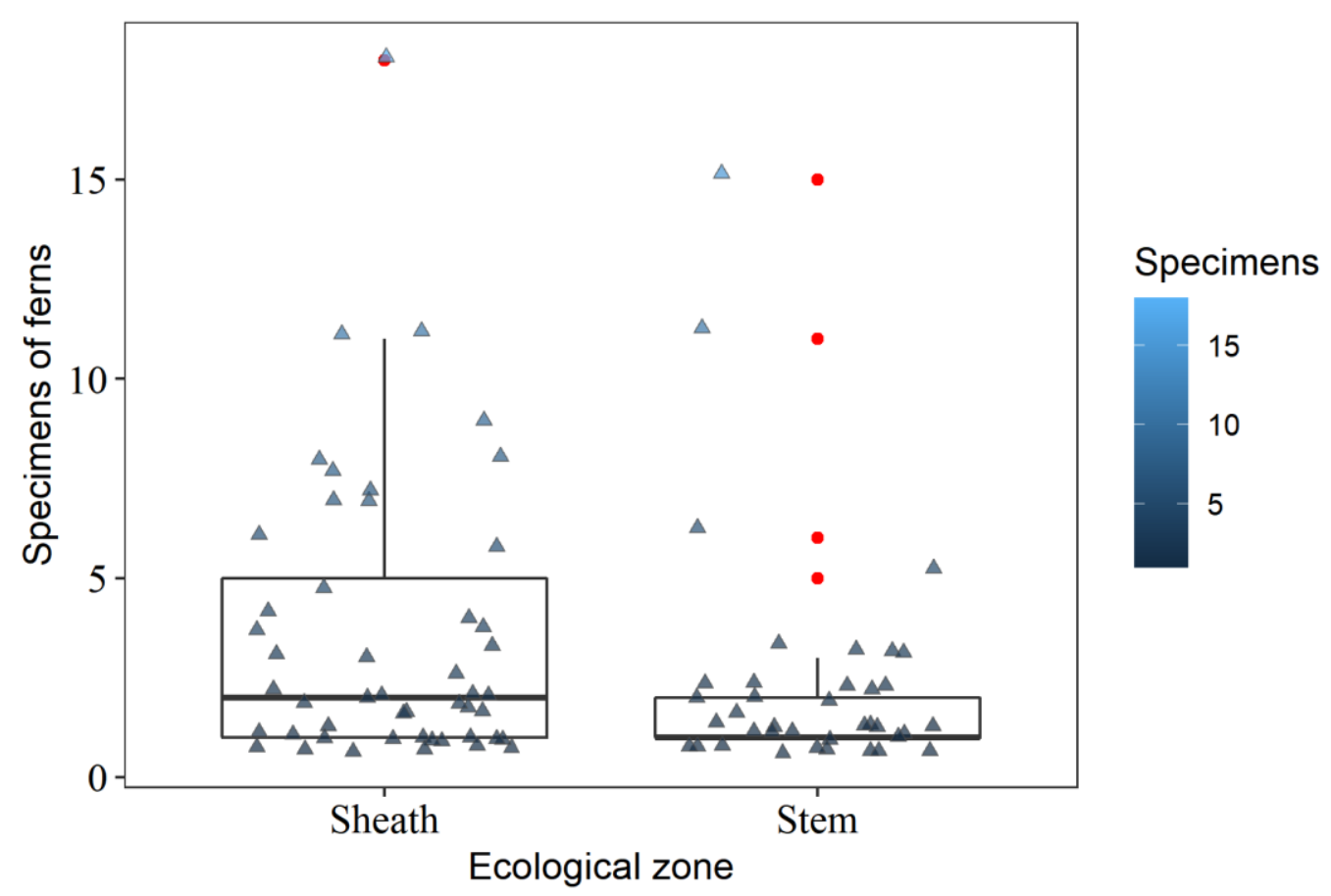

Figure 4: Number of ferns that occur in the ecological zone of the stem and leaf sheath. •- outliers; $\Delta$ distribution of specimens.

\subsection{Spearman correlation}

A total of 91 specimens of Attalea maripa (Aubl.) Mart. were recorded with epiphytic fern species. As for the number of ferns per phorophyte, 38 (41.7\%) of the 91 phorophytes presented only one individual and the maximum number of ferns found on a single phorophyte was 18 specimens. Table 2 describes the averages and their variations from the measures observed in specimens of A. maripa. The results showed that there is no significant correlation between the number of fern specimens with the variables of TH $\left(r_{s}=0.05 p=0.39\right), D B H\left(r_{s}=0.04 p=0.47\right), S H$ $\left(\mathrm{r}_{\mathrm{s}}=0.06 \mathrm{p}=0.32\right)$ and the SHI $\left(\mathrm{r}_{\mathrm{s}}=0.02 \mathrm{p}=0.68\right)$.

Table 2: Variables observed in the Attalea maripa (Aubl.) Mart. found in the Ecological Reserve of Mata do Bacurizal, Salvaterra, Marajó Island, Pará.

\begin{tabular}{lccc}
\hline Variables & Minimum & Maximum & Media \\
\hline DBH (m) & 0.14 & 0.49 & 0.26 \\
TH (m) & 3.77 & 20.88 & 9.31 \\
SH (m) & 0.29 & 17.69 & 4.29 \\
SHI (m) & & 15.66 & 2.92 \\
Number of specimens per forophyte & 1 & 18 & 7.72 \\
\hline
\end{tabular}




\section{DISCUSSION}

\subsection{Species Richness}

Ferns form the second group (29\%) with the greatest diversity of epiphytes [26] and the low richness found in this study may be related both to the only species of phorophyte investigated and to the conditions of the microhabitat in the vertical distribution that can limit the fundamental and perceived niche that are exploited by different species [27, 28]. Similar results were recorded in the Caatinga in the Vale do Catimbau National Park, in Pernambuco [29], on this occasion; the authors analyzed the fern community of 100 forophytes of the species Syagrus coronata (Mart.) Beec, and identified only six species of epiphytic ferns.

Almost all genera of Polypodiaceae are adapted to the epiphytic habit, which makes this taxon more common among epiphytic ferns in different environments [30, 19], being common in altered areas (such as the Ecological Reserve of Mata do Bacurizal), and considerably most representative in restingas [31, 8]. The other families registered in this study are often raised in anthropized environments, such as Lomariopsidaceae [32] and Pteridaceae [33]. The first was represented by Nephrolepis biserrata (Sw.) Schott, found in other studies with a high number of specimens in areas with edge areas $[32,34]$. The species $N$. biserrata it occurs in all states in the northern region of Brazil, often found with an epiphytic habit on palm trees and on the edges of forest fragments [35].

According to Smith et al. (2006) [36], Pteridaceae it is the taxon with the greatest range of distribution in the tropics, which is characterized by great specific richness in tropical forests. This family was mentioned with six species recorded in a remnant of lowland Atlantic forest in Rio Formoso (PE), of which, Vittaria lineata (L.) Sm. similar to the present study, it also occurred with epiphytic habit [37]. Specimens of $V$. lineata they were reported to occur in the entire ombrophilous forest and in the igapó forest near the banks of the rivers in the Experimental Field of Embrapa Amazônia Oriental, municipality of Moju (PA) [38]. These two environments mentioned above, present high humidity and greater heterogeneity of microhabitat, increasing the chances of colonization of species dependent on water for reproduction, which is probably related to the low representativeness of $V$. lineata in the Bacurizal Ecological Reserve.

The low representativeness of specimens from Lygodium venustum $\mathrm{Sw}$ in the palm tree $A$. maripa it is related to the habit of this species, that is, terrestrial plants of a scandant habit [39, 40, 41]. The species L. venustum was also mentioned by Fernandes et al. (2010) [42] with occurrences in edge areas and clearings of forest fragments in the state of Maranhão.

\subsection{Ecological Zone}

The greater representativeness of specimens in the stem and sheath area may be related to the best microclimatic conditions in these environments, which have low temperatures and higher humidity that favor the establishment and development of fern communities [43]. According to Irume et al. (2013) [44], the occupation by epiphytes in phorophytes may be linked to their individual characteristics. Thus, the greater the establishment of epiphytic ferns in the sheath may be related to the accumulation of organic matter and high humidity in this microhabitat. Most records of Vittaria lineata (L.) Sm. in the phorophyte stem they were associated with the populations of bryophytes, probably due to the positive correlation already mentioned by Krömer et al. (2013) [45], between the humidity provided by the bryoflora of a given phorophyte and the establishment of ferns.

\subsection{Spearman Correlation}

The potential of palm trees as phorophytes was evidenced in the work of Hernández-Rosas (2001) [46] with Oenocarpus batatau Mart. as one of the species most used by epiphyte plants in the tropical forest of the Alto Orinoco Biosphere Reserve, Venezuela. For Irume et al. (2013) 
[44], palm trees stand out as phorophytes due to their wide distribution and density in disturbed areas.

The non-correlation between palm variables Attalea maripa (Aubl.) Mart. with the fern communities indicate that other variables must be determining the permanence of these specimens in the microhabitat. Zotz and Vollrath (2003) [47] noticed the absence of correlation of the palm DBH Socratea exorrhiza (Mart.) H. Wendl. With the occurrence of epiphytic bryophytes. In another study, Machado, Gonzatti and Windisch (2016) [48], also found no relationship between the variables of the forophytes and their epiphytic fern community.

In relation to other possible variables, which may be acting on the results of the present study, Medeiros, Jardim and Quaresma (2014) [49] realized that the abundance of epiphyte orchids was influenced by the roughness of the bark and correlated to the larger diameters of the forophytes with classes 2 (31.8 63.7) and 3 (63.7- 95.5). Regarding the importance of DBH, Nieder et al. (2000) [50] found in a flooded forest in Venezuela, that all orchids occur in phorophytes with DBH greater than or equal to $30 \mathrm{~cm}$, showing that epiphytic orchids are preferred by larger phorophytes.

\section{CONCLUSION}

Palm tree Attalea maripa (Aubl.) Mart. proved to be an important component for the establishment of epiphytic fern communities in edge areas, if we consider that this species is recognized by the high frequency of species in the Ecological Reserve of Mata do Bacurizal. Probably, the niche of the ecological zone of the sheath presented microclimatic conditions in the tolerance range most suitable for the establishment, and development of ferns that are sensitive plants and dependent on water for reproduction. It is expected that in this scenario A. maripa, assist in the recovery and maintenance of biodiversity, supporting not only fern communities, but also organisms that need the same environmental conditions for survival. Studies aimed at analyzing other variables that may be influencing the floristic composition of fern communities, as well as their richness and abundance, are recommended for a better understanding of the relationships between epiphytes and phorophytes.

\section{REFERENCES}

1. Balmford A, Green R, Phalan B. What conservationists need to know about farming. Proc Royal Soc B: Biol Sci. 2012;279(1739):2714-2724, doi:10.1001/archneur.62.1.112.

2. Bowman MS, Soares-Filho BS, Merry FD, Nepstad DC, Rodrigues H, Almeida OT. Persistence of cattle ranching in the Brazilian Amazon: a spatial analysis of the rationale for beef production. Land Use Pol. 2012;29:558-568, doi: 10.1016/j.landusepol.2011.09.009

3. Pfaff A, Robalino J, Reis EJ, Walker R, Perz S, Laurance W, Bohrer C, Aldrich E, Arima E, Caldas M, Kirby K. Roads \& SDGs, tradeoffs and synergies: learning from Brazil's Amazon in distinguishing frontiers. Economics. 2018;12(11):1-25, doi: 10.5018/economics-ejournal.ja.2018-11

4. Monteiro MA. Meio século de mineração industrial na Amazônia e suas implicações para o desenvolvimento regional. Estud Av. 2005;19(53):187-207, doi: 10.1590/S0103-40142005000100012.

5. Capobianco JPR, Veríssímo A, Moreira A, Sawyer D, Santos I, Pinto LP. Biodiversidade na Amazônia brasileira: avaliação e ações prioritárias para a conservação, uso sustentável e repartição dos benefícios. São Paulo: Estação Liberdade, Instituto Socioambiental; 2001. 540 p.

6. MMA. Áreas Prioritárias para Conservação, Uso Sustentável e Repartição de Benefícios da Biodiversidade Brasileira: Atualização - Portaria MMA n 9, de 23 de janeiro de 2007. Série Biodiversidade 31. Brasília: Ministério do Meio Ambiente; Secretaria de Biodiversidade e Florestas.

7. Lisboa PLB, Lisboa RCL, Rosa NA, Santos MR. Padrões de diversidade florística na Reserva Ecológica de Bacurizal, em Salvaterra, Ilha do Marajó, Pará. Bol Mus Para Emílio Goeldi, Série Botânica. 1993;9(2):223-248.

8. Pereira AFN, Prado J. Efeito de borda sobre a comunidade de samambaias em fragmento de floresta atlântica (Bonito, Pernambuco, Brasil). Interciência. 2014;39(4):281-287.

9. Lacasella F, Gratton C, Felici S, Isaia M, Zapparoli M, Marta S, Sbordoni V. Asymmetrical responses of forest and "beyond edge" arthropod communities across a forest-grassland ecotone. Biodiv Conserv. 2015;24(3):447-465. 
10. Bezerra VS. O Inajá (Maximiliana maripa (Aubl.) Drude) como fonte alimentar e oleaginosa. 2011. Comunicado Técnico, Macapá, n. 129.

11. Matos AKMG, Rosa LS, Pires HCG, Cabral BS, Vieira TA, Silva VM. Morfotipos de frutos e morfologia de plântulas de Attalea maripa (Aubl.) Mart. Ciên Florestl. 2017;27(3):819-829.

12. Ribeiro JELS, Hopkins MJG, Vicentini A, Sothers C, Costa MA, Martins LHP, Lohmann LG, Assunção PACL, Pereira E, Silva CF, Mesquita MR, Procópio LC. Flora da Reserva Ducke. Guia de identificação das plantas de uma floresta de terra-firme na Amazônia Central. Manaus: INPA; 1999. 816 p.

13. Oliveira J, Potigara RCV, Lobato LCB. Fibras vegetais utilizadas na pesca artesanal na microrregião do salgado, Pará. Bol do Mus Para Emilio Goeldi, Ciências Humanas. 2006;1(2):113-127, doi: 10.1590/S1981-81222006000200009.

14. Nieder J, Prosperí J, Michaloud G. Epiphytes and their contribution to canopy diversity. Plant Ecol. 2001;153:51-63, doi: 10.1023/A:1017517119305

15. Kress WJ. A symposium: The biology of tropical epiphytes. Selbyana. 1986;9:1-22.

16. Laurance WF, Vasconcelos HL. Consequências ecológicas da fragmentação florestal na Amazônia. Oecologia Brasiliensis. 2009;13:434-451, doi: 10.4257/oeco.2009.1303.03

17. Gentry AH, Dodson CH. Diversity and Biogeography of Neotropical Vascular Epiphytes. Mo Bot Gard. 1987;74(2):205-233, doi: 10.2307/2399395

18. Sharpe JM, Mehltreter K, Walker LR. Ecological importance of ferns. In: Mehltreter K, Walker LR, Sharpe JM, editors. Fern Ecology. 1. ed. New York: Cambridge University press; 2010. p. 1-17.

19. Prado J, Sylvestre LS, Labiak PH, Windisch PG, Salino A, Barros ICL, Hirai RY, Almeida TE, Santiago ACP, Kieling-Rubio MA, Pereira AFE, Øllgaard B, Ramos CGV, Mickel JT, Dittrich VAO, Mynssen CM, Schwartsburd PB, Condack JPS, Pereira JBS, Matos FB. Diversity of ferns and lycophytes in Brazil. Rodriguésia. 2015;66(4):1073-1083, doi: 10.1590/2175-7860201566410..

20. Johansson DR. Ecology of vascular epiphytes in West African rain forest. Acta Phytogeographyca Suecica. 1974;59:1-136.

21. Kersten RA, Waechter JL. Métodos quantitativos no estudo de comunidades epifíticas. In: Felfili-Fagg JM, Eisenlohr PV, Melo MMRF, Andrade LA, Meira-Neto JAA, editors. Fitossociologia no Brasil: métodos e estudos de caso. 1 ed. Viçosa: Editora da Universidade Federal de Viçosa; 2011. p. 231-254.

22. Smith AR, Pryer KM, Schuettpelz E, Korall P, Schneider H, Wolf PG. Fern classification. In: Ranker TA, Haufler $\mathrm{CH}$, editors. Biology and evolution of ferns and lycophytes. New York: Cambridge University Press; 2008. p. 417-467.

23. Windisch PG. Pteridófitas da Região Norte-Ocidental do Estado de São Paulo: guia para excursões. 2.ed. São José do Rio Preto: UNESP; 1992. 110 p.

24. Zuquim G, Costa FRC, Prado J, Tuomisto H. Guia de samambaias e licófitas da REBIO Uatumã Amazônia Central. Manaus: Attema; 2008. 316 p.

25. Zar JH. Biostatistical Analysis. 5. ed. New Jersey: Pearson Prentice-Hall, Upper Saddle River; 2010.

26. Dubuisson JY, Schneider H, Hennequin S. Epiphytism in ferns: diversity and history. C R Biol. 2009;332:120-128, doi: 10.1016/j.crvi.2008.08.018

27. Steege H, Cornelissen JHC. Distribution and Ecology of vascular epiphytes in lowland rain forest of Guyana. Biotropica. 1989;21:331-339, doi: 10.2307/2388283

28. Werneck MS, Espírito-Santo MM. Species diversity and abundance of vascular epiphytes on Vellozia piresiana in Brazil. Biotropica. 2002;34:51-57, doi: 10.1646/00063606(2002)034[0051:SDAAOV]2.0.CO;2

29. Castro RA, Fabricante JR, Siqueira-Filho JA. A importância da palmeira Syagrus coronata (Mart.) Beec. para a conservação da riqueza e diversidade de espécies epífitas vasculares na Caatinga. Rev Árvore. 2016;40(1):1-12, doi: 10.1590/0100-67622016000100001

30. Alves MEO, Brun C, Forno RSD, Essi L. Levantamento de espécies epífitas vasculares da zona urbana do município de Palmeira das Missões, RS, Brasil. Ciên Natura. 2014;36(3):268-276, doi: $10.5902 / 2179460 X 12437$.

31. Athayde-Filho FP, Windisch PG. Florística e aspectos ecológicos das pteridófitas em uma floresta de Restinga no estado do Rio Grande do Sul, Brasil. Iheringia, Série Bot. 2006 Jan/Dez;61(1-2):63-71.

32. Paciencia MLB, Prado J. Efeitos de borda sobre a comunidade de pteridófitas na Mata Atlântica da região de Una, sul da Bahia, Brasil. Rev Bras Bot. 2004;27:641-653, doi: 10.1590/S010084042004000400005 .

33. Graçano D, Prado J, Azevedo AA. Levantamento preliminar de Pteridophyta do Parque Estadual do Rio Doce (MG). Acta Bot Bras. 1998;12(2):165-181, doi: 10.1590/S0102-33061998000200006.

34. Conceição GM, Zárate ELP, Ruggieri AC, Silva EO, Silva MF. Pteridoflora e seus aspectos ecológicos no município de Timon, Maranhão, Brasil. Braz Geogr J. 2015;6(1):74-81.

35. Maciel S. Nephrolepis (Lomariopsidaceae-Polypodiopsida) na Amazônia brasileira. Rodriguésia. 2016;67(1):77-84, doi: /10.1590/2175-7860201667106 
36. Smith AR, Pryer KM, Schuettpelz E, Korall P, Schneider H, Wolf PG. A classification for extant ferns. Taxon. 2006;55(3):705-731, doi: 10.2307/25065646

37. Costa LEN, Souza KRMS, Silva IAA, Farias RP, Barros ICL. Florística e aspectos ecológicos de samambaias em um remanescente de Floresta Atlântica de terras baixas (Rio Formoso, Pernambuco, Brasil). Pesquisas: Botânica. 2013;64:259-271.

38. Maciel S, Pietrobom MR. Pteridaceae (Polypodiopsida) do Campo Experimental da Embrapa Amazônia Oriental, município de Moju, estado do Pará, Brasil. Acta Bot Bras. 2010;24:8-19, doi: 10.1590/S0102-33062010000100002.

39. Aguiar TM, Góes-Neto LAA, Macedo TS. Samambaias do parque Zoobotânico Getúlio Vargas, Salvador, Bahia. Candombá, Rev Virtual. 2012;8(1):1-18.

40. Góes-Neto LAA, Pietrobon MR, Maciel S. Schizaeales (Polypodiopsida) do corredor de biodiversidade do norte do Pará, Brasil. Pesquisas: Botânica. 2014;65:245-256.

41. Silvestre LC, Mendonça JDL, Xavier SRS, Jardim JG. Riqueza e similaridade florística de samambaias e licófitas na floresta atlântica no nordeste do Brasil. Oecol Austral. 2019;1-34, doi: 10.4257/oeco.2019.2303.08

42. Fernandes RS, Conceição GM, Costa JM, Paula-Zárate EL. Samambaias e licófitas do município de Caxias, Maranhão, Brasil. Bol Mus Para Emílio Goeldi, Série Botânica. 2010;5(3):345-356.

43. Sota ER. El epifitismo y las pteridofitas en Costa Rica (América Central). Nova Hedwigia. 1971;21(14):401-465.

44. Irume MV, Morais MLCS, Zartman CE, Amaral IL. Floristic composition and community structure of epiphytic angiosperms in a terra firme forest in central Amazonia. Acta Bot Bras. 2013;279(2):378393, doi: 10.1590/S0102-33062013000200012

45. Krömer T, Acebey A, Kluge J, Kessler M. Effects of altitude and climate in determining elevational plant species richness patterns: A case study from Los Tuxtlas, Mexico. Flora. 2013;208(3):197-210, doi: /10.1016/j.flora.2013.03.003

46. Hernández-Rosas JI. Ocupación de los portadores por epifitas vasculares en un bosque húmedo tropical del Alto Orinoco, Edo. Amazonas, Venezuela. Acta Cient Venez. 2001;52(4):292-303.

47. Zotz G, Vollrath B. The epiphyte vegetation of the palm Socratea exorrhiza - correlations with tree size, tree age and briophyte cover. J Trop Ecol. 2003;19:81-90, doi: 10.1017/S0266467403003092

48. Machado LS, Gonzatti F, Windisch PG. Epiphytic ferns in swamp forest remnants of the coastal plain of southern Brazil: latitudinal effects on the plant community. Acta Bot Bras. 2016;30(4), doi: 10.1590/0102-33062016abb0319

49. Medeiros TDS, Jardim MAG, Quaresma AC. Forófitos preferenciais de orquídeas epífitas na APA Ilha do Combu, Belém, Pará, Brasil. Biota Amazônia. 2014;4(3):1-4, doi: 10.18561/21795746/biotaamazonia.v4n3p1-4

50. Nieder J, Engwald S, Klawun M, Barthlott W. Spatial distribution of vascular epiphytes (including hemiepiphytes) in a lowland amazonian rain forest (Surumoni crane plot) of southern Venezuela. Biotropica. 2000;32:385-396, doi: 10.1646/0006-3606(2000)032[0385:SDOVEI]2.0.CO;2 